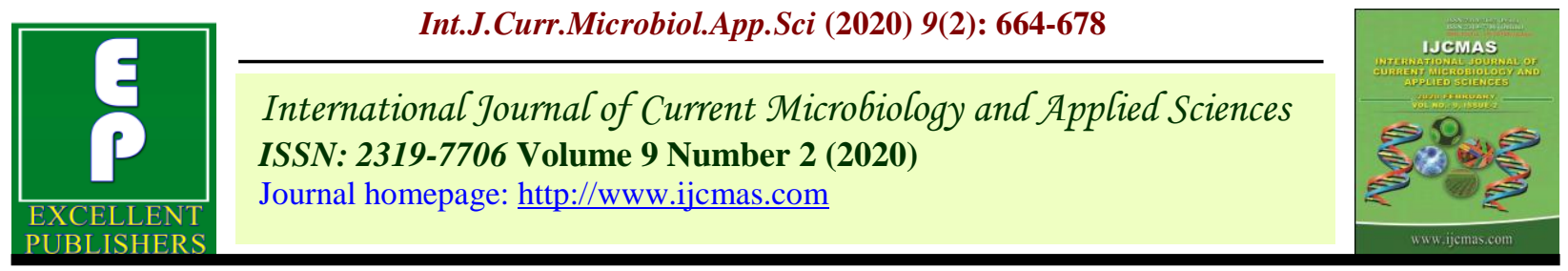

Original Research Article

https://doi.org/10.20546/ijcmas.2020.902.082

\title{
Calibration and Validation of HEC-RAS Model for Minor Command in Coastal Region
}

\author{
Vedmani*, Rabindra Kumar Panda and Vinay Kumar Pandey
}

Department of Soil and Water Engineering, SVCAET \& RS, FAE, IGKV Raipur (C.G.), India

*Corresponding author

Keywords

HEC-RAS model,

Minor canal command

Article Info

Accepted:

08 January 2020

Available Online:

10 February 2020

\section{A B S T R A C T}

In this study HEC-RAS model was used for the hydraulic analysis of the Nagpur minor canal irrigation system. Hydraulic models are the basic tools for understanding the hydraulic flow behaviours of open channels. Manning's roughness is very sensitive parameters in development of the hydraulic models. It is necessary to calibrate the Manning's coefficient ("n") values. HEC-RAS Model was used for calibrated and validated the sets of observed water depth and simulated water depth. The model was run with different values of ' $n$ ' between 0.016 and 0.033 and the calibrated Manning's n value was obtained as 0.0165 . Model performance has been tested using the six statistical criteria These are Nash-Sutcliffe efficiency (NSE), root mean squared error (RMSE), normalized root mean squared error (N RMSE), correlation coefficient (r) mean absolute error (MAE) and standard error of estimate (SEE), There has been relatively superior calibration and validation of model was observed at all five locations.

\section{Introduction}

Odisha is one of the 29 states of India, located in eastern India. The basic source of irrigation is rainfall and canal system in Odisha. For east central India Mahanadi is major river, drains an area of around 141600 square $\mathrm{km}$ and has a total course of $858 \mathrm{~km}$. Mahanadi Delta covers coastline of $200 \mathrm{~km} \&$ area of $9,500 \mathrm{~km}^{2}$ accounting for $7 \%$ of Odisha state's geographical area. Khurda district with an area of $2813 \mathrm{sq}$. km. has a vast network of irrigation system. Out of this, Puri main canal system with its network caters to the needs of the farming community to varying degrees of success through delivery of water in crop fields as per the farmer's interaction and field visits. Nagpur minor, one of the minor irrigation systems directly off takes from Puri main canal at RD $35.620 \mathrm{~km}(\mathrm{~L})$ in the district of Khurda (Odisha) is located in Hirapur and Nagpur village of block-Balianta. Nagpur minor canal length of approx.3.02km; the design Culturable Command Area of 156ha; 
and design discharge of 0.31 cumec is under performing in delivery of water to crop fields. The system is poor performing between its demand requirements and actual supply.

\section{Description about the HEC-RAS Model}

Hydraulic models are the basic tools for understanding the flow behaviour of flowing water in open channels. In the present study HEC-RAS model is used for understanding the hydraulic behaviour of Nagpur minor irrigation system. HEC-RAS model is used for the error estimation and canal used to determine the new cross-sections for increasing the capacity of the canal.

\section{HEC-RAS Model}

The Hydrologic Engineering Center's (HEC) River Analysis System (RAS) model developed by the Hydrologic Engineering Center of the United States Army Corps of Engineers. HEC-RAS developed for modelling water flowing through system of open channels and calculating water surface profile. It performs one dimensional (1-D) steady and unsteady flow river hydraulics calculations.

\section{Hydraulic capabilities of HEC-RAS model}

1-D River analysis component for-

1. Steady flow water surface profile calculation.

2. Unsteady flow calculation.

3. Sediment transport computations

4. Water quality analysis.

In the present study HEC-RAS model $5.05 \mathrm{version}$ is used for understanding the hydraulic flow characteristic of Nagpur minor canal. HEC-RAS 5.05 supports the steady \& unsteady flow water surface profile calculations, sediment transports / mobile bed computation and water quality analysis.
HEC-RAS model employs a form of the Manning's equation to provide help the relationship between the rate of discharge, channel geometry, hydraulic resistance and rate of friction loss. In order to operationalize the Nagpur minor irrigation system to its fullest efficiency, an attempt is made to study its hydraulic flow characteristics through use of standard hydraulic performance indicators (Molden and Gates, 1990) and to work out suggestive measures in its functioning by using HEC-RAS model.

\section{Description of the study area}

The Study area is located between $85.88^{0} \mathrm{E}$ to $85.84^{0} \mathrm{E}$ longitudes and $22.22^{0} \mathrm{~N}$ to $22.20^{\circ} \mathrm{N}$ latitudes. The study area $(20 \mathrm{~km}$ away from Bhubaneswar), which is located near Khurda district area of Nagpur and Hirapur village, block-Balianta, Bhubaneswar, Odisha. The total length of Nagpur Minor canal is approx $3.02 \mathrm{~km}$. The required data of the study area were collected from the field as well as from the concerned institute/centre. The experiment (Modelling) was conducted in the Indian Institute of Water Management, Bhubaneswar Odisha. The study area is shown in figure1.

Puri main canal system with its vast network in Odisha caters to the needs of the farming community to varying degrees of success through delivery of water in crop fields. Nagpur minor, one of the minor irrigation system directly off taking from Puri main canal at RD $35.620 \mathrm{~km}$ (L)in the district of Khurda (Odisha) located in Hirapur and Nagpur village of block-Balianta having length of approximately $3.02 \mathrm{~km}$; the design Culturable Command Area (CCA) of 156 ha; and design discharge of 0.31 cumec is no exception also. In fact, as per the farmers direct interaction and field visits, the system was found under performing between its demand requirements and actual supply. 


\section{Water surface profile calculation method used in HEC-RAS model}

The two method are used-

1) Direct method.

2) Standard step method.

The direct method is a procedure in which the water depth is known at two locations and the distance between the two locations is considered (Kragh, 2011). Standard step method on the other side applies the hydraulic equations to iteratively calculate water surface profiles and energy grade lines.

Standard step method is a procedure in which the conservation of energy equation apples in the calculation of water-surface elevations and energy lines along the reach between cross-sections. In below Figure-

\section{One dimensional steady flow water surface profile computations}

HEC-RAS is capable of the performing water surface profile for steady gradually varied flow in natural and manmade constructed channels. It is calculate the sub-critical, supercritical and mixed flow regime water surface profiles.

\section{The basic fundamental equations for the} water surface profile computations

The basic hydraulic equations for 1-D, steadystate and gradually-varied flow analysis is the continuity, energy and flow resistance equations. In case of the continuity equation describes discharge as a constant and continuous over a specified period of time. This equation is given as:

$$
\mathrm{Q}=V_{1} A_{1}=V_{2} A_{2}
$$

Where,
$\mathrm{Q}=$ Discharge in $\mathrm{m}^{3} / \mathrm{s} \quad V_{1=}$ Average velocity at the downstream $(\mathrm{m} / \mathrm{s}), \quad V_{2}=$ Average velocity at the upstream $(\mathrm{m} / \mathrm{s}), A_{1}=$ Crosssectional area to the direction of flow at downstream cross-section $\left(\mathrm{m}^{2}\right), A_{2}=$ Crosssectional area to the direction of flow at the upstream cross-section $\left(\mathrm{m}^{2}\right)$

The basic energy equation is used to calculate the total head of water at given cross-section taken bed elevation; average flow depth and the velocity head this equation shown in below

$H=Z+y+\frac{\alpha v^{2}}{2 g}$

Where,

$\mathrm{H}=$ Total head of water $(\mathrm{m}), \alpha=$ Kinetic energy correlation coefficient, $Z=$ Bed elevation at a cross-section (m), y = Flow depth at a cross-section $(\mathrm{m}), \mathrm{g}=$ Acceleration of gravity $\left(\mathrm{m}^{2} / \mathrm{s}\right), \bar{v}=$ Average velocity $(\mathrm{m} / \mathrm{s})$

When considered two channel sections, A and $B$ with reference to a datum, Equation becomes:

$\mathrm{Z}_{\mathrm{A}}+\mathrm{y}_{\mathrm{A}}+\frac{a v^{2}}{2 \mathrm{~g}}=\mathrm{Z}_{\mathrm{A}}+\mathrm{y}_{\mathrm{A}}+\frac{a v^{2}}{2 \mathrm{~g}}+\mathrm{H}_{\mathrm{L}}$

In open channels flows, the energy equation according to USACE (2008) becomes:

$\left(\frac{d A}{d t}\right) \Delta t=-V_{m}\left(\frac{d A}{d L}\right)-V A_{m}\left(\frac{d A}{d L}\right.$

Where,

$\mathrm{m}=$ subscriptions for the mean values of $\mathrm{V}$ and $\mathrm{A}, \mathrm{L}=$ Channel length $(\mathrm{m}), \mathrm{t}=$ Incremental time to be calculated

Energy loss between two cross-sections is calculated using below Equation

$\left.\mathrm{h}_{\mathrm{e}}=\mathrm{LS}_{\mathrm{f}}+\mathrm{C}_{[} \alpha_{2} \frac{\mathrm{v}^{2}}{2 \mathrm{~g}}+\alpha_{1} \frac{\mathrm{v}_{1}^{2}}{2 \mathrm{~g}}\right]$ 
Where,

$h_{e}=$ energy head loss, $\mathrm{L}=$ discharge weighted reach length , $\mathrm{S}_{\mathrm{f}}=$ representative fraction slope between two stations, $C=$ expansion or Contraction loss coefficient, $\alpha_{1} \alpha_{2}=$ velocity weighting coefficients, $\mathrm{g}=$ gravitational acceleration, $v_{1}, v_{2}$ average velocities.

Flow resistance equations used for friction losses estimation are computed with a friction slope from Manning's equation as presented in Equation

$$
Q=K S_{f}^{1 / 2}
$$

Where, $\mathrm{Q}=$ discharge $(\mathrm{m} 3 / \mathrm{s}), \mathrm{K}=$ channel conveyance, $S_{f}=$ friction slope $(\mathrm{m} / \mathrm{m})$

Conveyance at a cross-section is obtained by Equation

$K=\frac{\Phi}{n} A R^{\frac{2}{a}}=\frac{\Phi}{n} A(A / p)^{\frac{2}{\pi}}$

Where,

$\mathrm{A}=$ Cross-sectional area normal to the direction of flow $\left(\mathrm{m}^{2}\right), \Phi=$ Unit conversion ( $\mathrm{SI}=1.000), \mathrm{K}=$ Channel conveyance $(\mathrm{m}), \mathrm{n}=$ Roughness coefficient, $\mathrm{P}=$ Wetted perimeter (m), $\mathrm{R}=$ Hydraulic radius $(\mathrm{m})$.

The cross-sectional area and wetted perimeter are a function of channel geometry. If the cross-section is trapezoidal, then the equations used are given as:

$A=y(b+z y)$

$P=b+2 y\left(\sqrt{z^{2}+1}\right)$

Where,

$\mathrm{A}=$ cross-sectional area normal to the direction of flow $\left(\mathrm{m}^{2}\right), \mathrm{P}=$ wetted perimeter $(\mathrm{m}), \mathrm{y}=$ flow depth at a cross-section $(\mathrm{m}), \mathrm{z}=$ side slope of the channel

\section{Basic input data for 1-D steady gradually varied profile calculations}

HEC-RAS model is completely dependent on input data set. To perform the 1-D steady state hydrodynamic modelling the following data's are required- Canal geometry (detailed crosssection of canal, length bottom width top width, depth, side slope),Slope of the canal or channel bed, Manning's roughness coefficient ' $n$ ' value,Past peak discharged data,Reduce level of both (LB \&RB) banks, Downstream reach length of the both left and right bank, Energy loss coefficient for hydraulic resistance and the expansion or contraction of flow, discharge and conditions for the flow boundaries of canal (i.e. top of lining. Crosssectional geometry data collected from water resource department Govt. of Odisha. Five cross-sections are selected were at interval first location to last fifth location length about $253 \mathrm{~m}, 552 \mathrm{~m}, 1539 \mathrm{~m}$ and $674 \mathrm{~m}$ along the Nagpur minor canal. The distribution of cross-sections differ from station to station depends on site specific features such as longitudinal uniformity of cross-sectional shape, channel linearity, degree of channel meander, longitudinal slope and uniformity of slope throughout the study reach.

\section{Model parameter}

Manning's roughness-coefficient is the only one parameter used for model calibration and validation in the present analysis. Roughness coefficient is sensitive parameters used to reflect the resistance to flow at the canal bottom. Nagpur minor canal is excavated type channel for this type of channel Manning's roughness coefficient ranges from 0.0160.033 (chow 1959). So the model was run between these ranges. 


\section{Model calibration}

The time of the model calibration Total 40 events (discharge and observed water depths) are taken out of the 60 events date data and calibrate the model with different values of Manning's roughness coefficient until the difference between simulated water depth and observed water depth within the allowable criteria ranges.

During the model calibration all input crosssection at every station upstream to downstream data's are entered, Manning's roughness coefficient value enter then select the steady flow editor then enter the discharge data for every cross-section select boundary condition for total reach (upstream to downstream) and enter boundary condition for total reach. When all the data enters then run the HEC-RAS model to compute the water level at every canal station, then Comparison between the observed water depth and simulated water depth at every canal station. This process is continuously performed until the difference between simulated water depth and observed water depth. The summary of the procedure followed is given in the flow chart in below Figure 4.The calibration procedure gave the actual Manning's roughness coefficient of the Nagpur minor canal.

\section{Model validation}

During the time of model verification, 20 events data selected out of the 60 events data. Model validation is the process of checking the accuracy of calibrated parameters. The accuracy of the calibrated parameter (Manning's ' $n$ ') was tested using the difference between the set of actual water depth data and the set of new simulated water depth data which validated the model. Model suitability was evaluated based on the difference between water simulated depth and observe water depth by performing the different statistical analysis.

\section{Model performance}

Model performance is necessary for the checking suitability of the model. The model suitability was evaluated based on the difference between water simulated depth and observe water depth by performing the different statistical analysis. Six statistical indicators were used to evaluate the performance of the calibrated and validated of the numerical model. They are Nash-Sutcliffe efficiency (NSE), root mean squared error (RMSE), normalised RMSE, correlation coefficient, mean absolute error (MAE) and standard error of estimate (SEE). Statistical indicators are expressed by the following equations:-

\section{(A). Nash- Sutcliffe efficiency (NSE)}

NSE $=\sum_{i=1}^{N}\left(h_{o i}-h_{s i}\right)^{2} / \sum_{i=1}^{N}\left(h_{o i}-\hbar_{o}\right)^{2}$

Where, NSE $=$ Nash Sutcliff efficiency, $\mathrm{N}=$ number of observations, $\mathrm{h}_{\mathrm{oi}}=$ observed water depth of the $i^{\text {th }}$ data, $h_{s}=$ simulated water depth of the $i^{\text {th }}$ data, ho $=$ mean of the observed water depth data

Nash- Sutcliffe efficiency can ranges from $-{ }^{\infty}$ to 1. An efficiency of (NSE=1) corresponds to a perfect match of model.

\section{(B). Root mean square error (RMSE)}

RMSE $=\sqrt{\sum_{i=1}^{N}\left(h_{s i}-h_{o i}\right)^{2}} / N$

Ideal condition when $\mathrm{RMSE}=0$

\section{(C). Normalized RMSE}

$\mathrm{N}$ RMSE $=\frac{\text { RMSE }}{\left(\mathrm{h}_{\mathrm{omax}}-\mathrm{h}_{\mathrm{omin}}\right)}$ 
Where, $\mathrm{N}$ RMSE = Normalized root mean square error, $\left(\mathrm{h}_{\mathrm{o}}\right)_{\max }=$ maximum observed water depth,$\left(h_{0}\right)_{\min }=$ minimum observed water depth

Ideal condition when $\mathrm{N}$ RMSE $=0$

\section{(D). Correlation coefficient (r)}

$r=\frac{\sum_{i=1}^{N}\left(h_{o i}-h_{o}\right)\left(h_{s i}-h_{g}\right)}{\sqrt{\sum_{i=1}^{N}\left(h_{o i}-h_{Q}\right)^{2}} \sum_{i=1}^{N}\left(h_{s i}-h_{S}\right)^{2}}$

When $\mathrm{r}=1$ give perfect match of model

(E). Mean absolute error (MAE)

MAE $=\frac{1}{N} \sum_{i=1}^{N} \mid$ hsi- hoi $\mid$

Ideal condition when $\mathrm{MAE}=0$

(F). Standard error of estimate (SEE)

$\mathrm{SEE}=\sqrt{\frac{\frac{1}{\mathrm{~N}-1} \sum_{\mathrm{i}=1}^{\mathrm{N}}\left[\left(\mathrm{h}_{\mathrm{gi}}-\mathrm{h}_{\mathrm{oi}}\right)-\frac{1}{\mathrm{~N}} \sum_{\mathrm{i}=1}^{\mathrm{N}}\left(\mathrm{h}_{\mathrm{gi}}-\mathrm{h}_{\mathrm{oi}}\right)\right]^{2}}{\mathrm{~N}}}$

Ideal condition when $\mathrm{SEE}=0$

\section{Results and Discussion}

\section{Manning's roughness coefficient}

The model was run with different values of ' $n$ ' between 0.016 and 0.033 . The simulated depth of flow data were compared with the observed depth of flow data. Finally the calibrated Manning's n value was obtained as 0.0165. In this analysis, the roughness coefficient has not varied horizontally across individual cross-section.

\section{Performance of Calibration\& Validation of the Model}

\section{Statistical criteria (indicators)}

Table 4 presents total six Statistical criteria (indicators) i.e. Nash-Sutcliffe efficiency, root mean squared error, normalized root mean squared error, correlation coefficient mean absolute error and standard error of estimate values at 5 locations during calibration of the model. The NSE values vary from a minimum of 0.805 at station 5 to a maximum of 0.918 at station 1, whereas the RMSE values range from a minimum of 0.001 at station 2 to a maximum of 0.01 at station 4. The N RMSE values vary from a minimum of 0.002 at station 2 to a maximum of 0.13 at station 5 , whereas the correlation coefficient values (r) vary from a minimum of 0.921 at station 5 to a maximum of 0.982 at station 4 . The MAE values ranges from a minimum of 0.003 at station 5 to a maximum of 0.009 at station 3, whereas the SEE the values range from a minimum of 0.002 at station $5,4 \& 3$ to a maximum of 0.004 at station 1 . Thus, there has been relatively superior calibration of model at all locations, as the values of MAE and RMSE values are on lower side and the values of NSE and $r$ are on a higher side.

The above figures represent the graph between observed water depth $\left(\mathrm{h}_{\mathrm{oi}}\right)$ \& simulated water depth $\left(\mathrm{h}_{\mathrm{si}}\right)$. During calibration, in canal station 5 and 4, the observed water depth and simulated water depth ranged from $0.3 \mathrm{~m}$ to $0.5 \mathrm{~m}$; but at canal station 3 , it ranged from $0.2 \mathrm{~m}$ to 0.45 $\mathrm{m}$; at canal station 2 it ranged from $0.2 \mathrm{~m}$ to $0.4 \mathrm{~m}$; and at canal station 1it ranged from 0.1 $\mathrm{m}$ to $0.3 \mathrm{~m}$.

\section{Model validation}

Total 20 event days discharge data were used for validation of the model for obtaining depth of flow data. Table 5 presents NashSutcliffe efficiency, root mean squared error, normalized root mean squared error, correlation coefficient, mean absolute error and standard error of estimate values at 5 locations during validation of the development of model. The NSE values vary from a minimum of 0.842 at canal station 4 to 
a maximum of 0.928 at canal station 1, whereas the RMSE values range from a minimum of 0.008 at canal station 1 to a maximum of 0.029 at canal station 3. The $\mathrm{N}$ RMSE values vary from a minimum of 0.076 at canal station 3 to a maximum of 0.116 at canal station 4, whereas the correlation coefficient values ( $r$ ) vary from a minimum of 0.963 at canal station 5 to a maximum of 0.985 at canal station 1 . The MAE values ranges from a minimum of 0.007 at canal station 1 to a maximum of 0.01 at canal station 2, whereas the SEE the values range from a minimum of 0.003 at canal station 2 to a maximum of 0.007 at canal station 1 . Thus, there has been relatively superior simulation of model at all locations.

The above Figures from 7 to 11 represent the graph between observed water depth $\left(\mathrm{h}_{\mathrm{oi}}\right) \&$ simulated water depth $\left(\mathrm{h}_{\mathrm{si}}\right)$. During validation period at $1^{\text {st }}$ and $2^{\text {nd }}$ cross-section observed water depth and simulated water depth ranges from $0.3 \mathrm{~m}$ to $0.5 \mathrm{~m}, 3^{\text {rd }}$ cross-section observed water depth \&simulated water depth ranges from $0.2 \mathrm{~m}$ to $0.45 \mathrm{~m}, 4^{\text {th }}$ cross-section observed water depth \&simulated water depth ranges from $0.2 \mathrm{~m}$ to $0.4 \mathrm{~m}$ and last crosssection observed water depth \&simulated water depth ranges from $0.1 \mathrm{~m}$ to $0.3 \mathrm{~m}$ shows in above figures. While calibration and validation of the canal reach for depth of flow was satisfactory by using HEC-RAS model, the water surface profile encountered error at reach 3 and reach 2; depicting the warning note of inadequate conveyance loss Fig 4.12.and Fig 4.13. This result may be attributed to sudden change in cross-section at reach 3 onwards i.e. with base width from 2.1 $\mathrm{m}$ to $1.2 \mathrm{~m}$ and top width from $5.1 \mathrm{~m}$ to 3.6 $\mathrm{m}$.

Table.1 Details of nagpur minor irrigation canal

\begin{tabular}{|l|l|l|l|l|l|l|}
\hline $\begin{array}{l}\text { Site } \\
\text { Name }\end{array}$ & District & $\begin{array}{l}\text { Total } \\
\text { Length } \\
\text { (km) }\end{array}$ & $\begin{array}{l}\text { CCA } \\
\text { (ha) }\end{array}$ & $\begin{array}{l}\text { Design } \\
\text { Discharge } \\
\text { (Cumec) }\end{array}$ & Longitudes & Latitudes \\
\hline $\begin{array}{l}\text { Nagpur } \\
\text { Minor }\end{array}$ & Khurda & 3.02 & 156 & 0.31 & $\begin{array}{l}85.88^{0} \mathrm{E} \text { to } \\
85.84^{0} \mathrm{E}\end{array}$ & $22.22^{0} \mathrm{~N}$ to $22.20^{0} \mathrm{~N}$ \\
\hline
\end{tabular}

Table.2 Summary of Data Collected During Field Work

\begin{tabular}{|l|c|c|c|c|c|}
\hline Station & $\begin{array}{c}\text { Distance } \\
(\mathbf{m})\end{array}$ & $\begin{array}{c}\text { Cumulative } \\
\text { Distance } \\
(\mathbf{m})\end{array}$ & $\begin{array}{c}\text { Base Width } \\
(\mathbf{m})\end{array}$ & $\begin{array}{c}\text { Depth } \\
\text { of anal } \\
(\mathbf{m})\end{array}$ & $\begin{array}{c}\text { Canal Top } \\
\text { Width }(\mathbf{m})\end{array}$ \\
\hline $\mathbf{5}$ & 0 & 0 & 2.1 & 1 & 5.1 \\
\hline $\mathbf{4}$ & 253 & 253 & 2.1 & 1 & 5.1 \\
\hline $\mathbf{3}$ & 552 & 805 & 2.1 & 1 & 5.1 \\
\hline $\mathbf{2}$ & 1539 & 2344 & 1.2 & 0.8 & 3.6 \\
\hline $\mathbf{1}$ & 674 & 3018 & 1 & 0.6 & 2.8 \\
\hline
\end{tabular}


Table.3 Manning's values used for the analysis of excavated Earth canal

\begin{tabular}{|l|l|l|l|}
\hline Types of channel & Minimum & Normal & Maximum \\
\hline $\begin{array}{l}\text { Excavated or dredged channels } \\
\text { Earth, straight and uniform }\end{array}$ & & & \\
\hline $\begin{array}{l}\text { 1. clean, recently completed } \\
\text { 2. clean, after weathering }\end{array}$ & 0.016 & 0.018 & 0.020 \\
\hline 3. gravel, uniform section, clean & 0.018 & 0.022 & 0.025 \\
\hline 4.with short grass, few weeds & 0.022 & 0.025 & 0.030 \\
\hline
\end{tabular}

[Source : Chow (1959)]

Table.4 Model performances statistic during calibration

\begin{tabular}{|c|c|c|c|c|c|c|}
\hline Station & NSE & RMSE & N RMSE & R & MAE & SEE \\
\hline $\mathbf{5}$ & 0.805 & 0.011 & 0.13 & 0.921 & 0.008 & 0.002 \\
\hline $\mathbf{4}$ & 0.873 & 0.01 & 0.09 & 0.982 & 0.007 & 0.002 \\
\hline $\mathbf{3}$ & 0.846 & 0.013 & 0.085 & 0.977 & 0.009 & 0.002 \\
\hline $\mathbf{2}$ & 0.885 & 0.001 & 0.002 & 0.972 & 0.006 & 0.003 \\
\hline $\mathbf{1}$ & 0.918 & 0.005 & 0.058 & 0.967 & 0.003 & 0.004 \\
\hline
\end{tabular}

Table.5 Model performances statistic during validation

\begin{tabular}{|l|l|l|l|l|l|l|}
\hline Location & NSE & RMSE & N RMSE & r & MAE & SEE \\
\hline $\mathbf{5}$ & 0.845 & 0.018 & 0.112 & 0.963 & 0.013 & 0.004 \\
\hline $\mathbf{4}$ & 0.842 & 0.016 & 0.113 & 0.964 & 0.011 & 0.004 \\
\hline $\mathbf{3}$ & 0.848 & 0.029 & 0.076 & 0.983 & 0.014 & 0.005 \\
\hline $\mathbf{2}$ & 0.856 & 0.013 & 0.116 & 0.983 & 0.01 & 0.003 \\
\hline $\mathbf{1}$ & $\mathbf{0 . 9 2 8}$ & $\mathbf{0 . 0 0 8}$ & $\mathbf{0 . 0 9 7}$ & $\mathbf{0 . 9 8 5}$ & $\mathbf{0 . 0 0 7}$ & $\mathbf{0 . 0 0 7}$ \\
\hline
\end{tabular}


Fig.1 Location of the study area
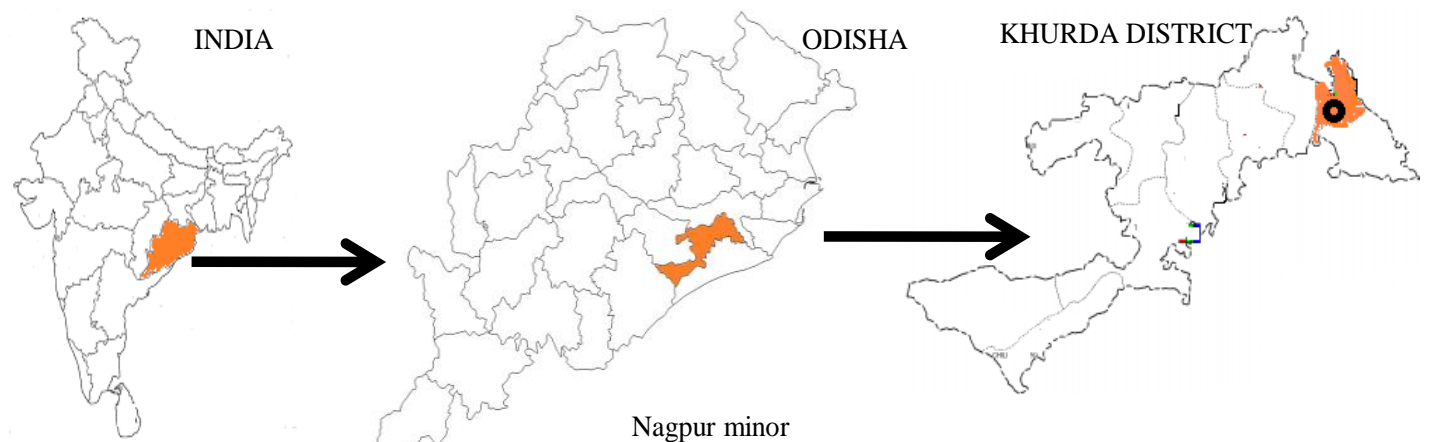

Nagpur minor

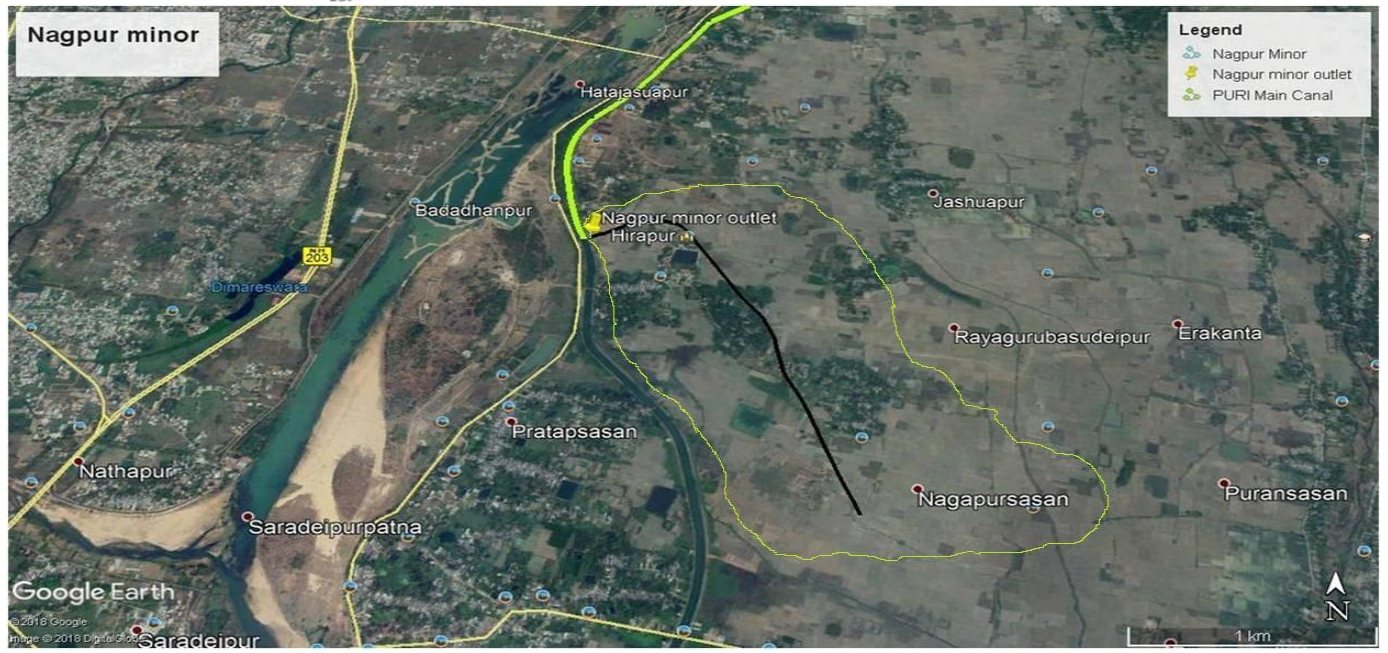

Fig.2 Water surface profiles and energy lines between two points

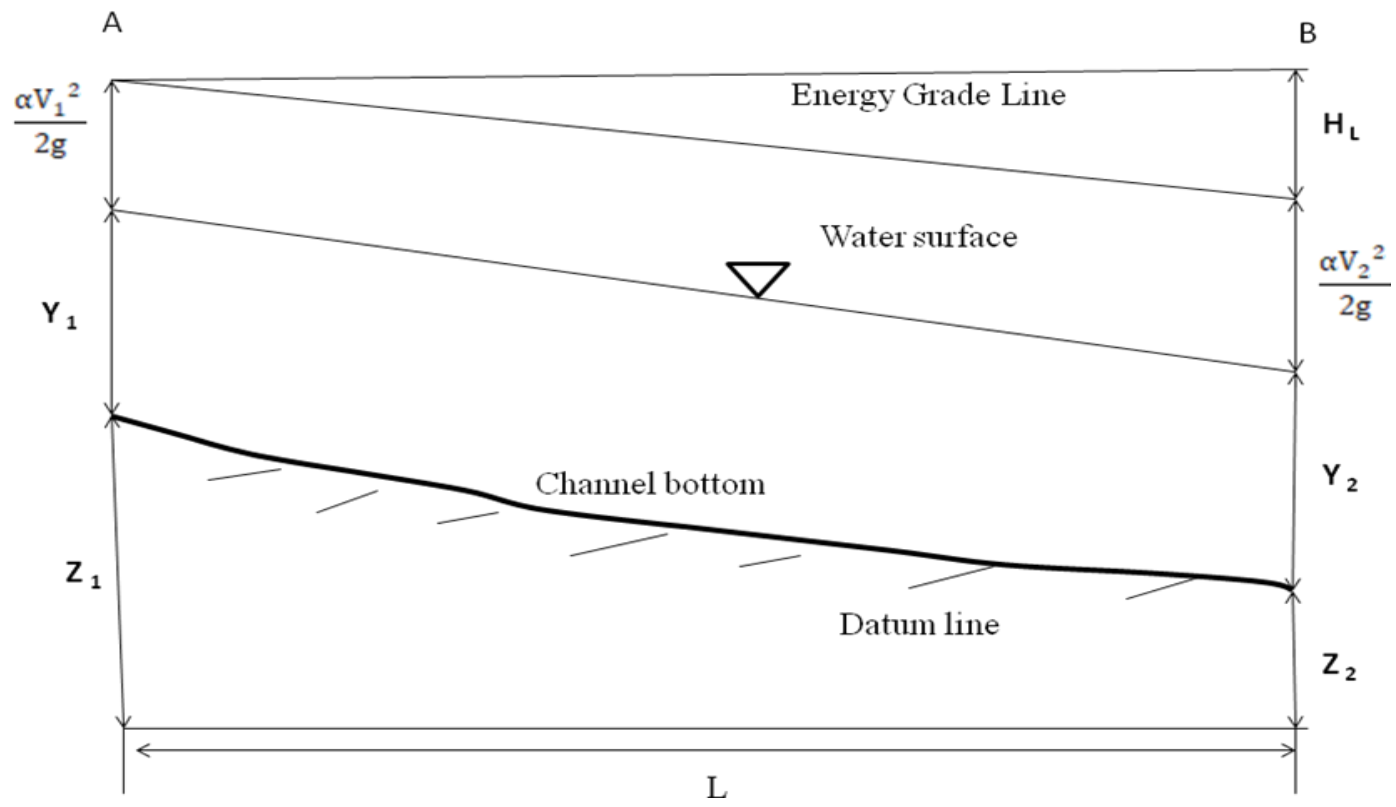


Fig.4 Conceptual flow chart of HEC-RAS Model

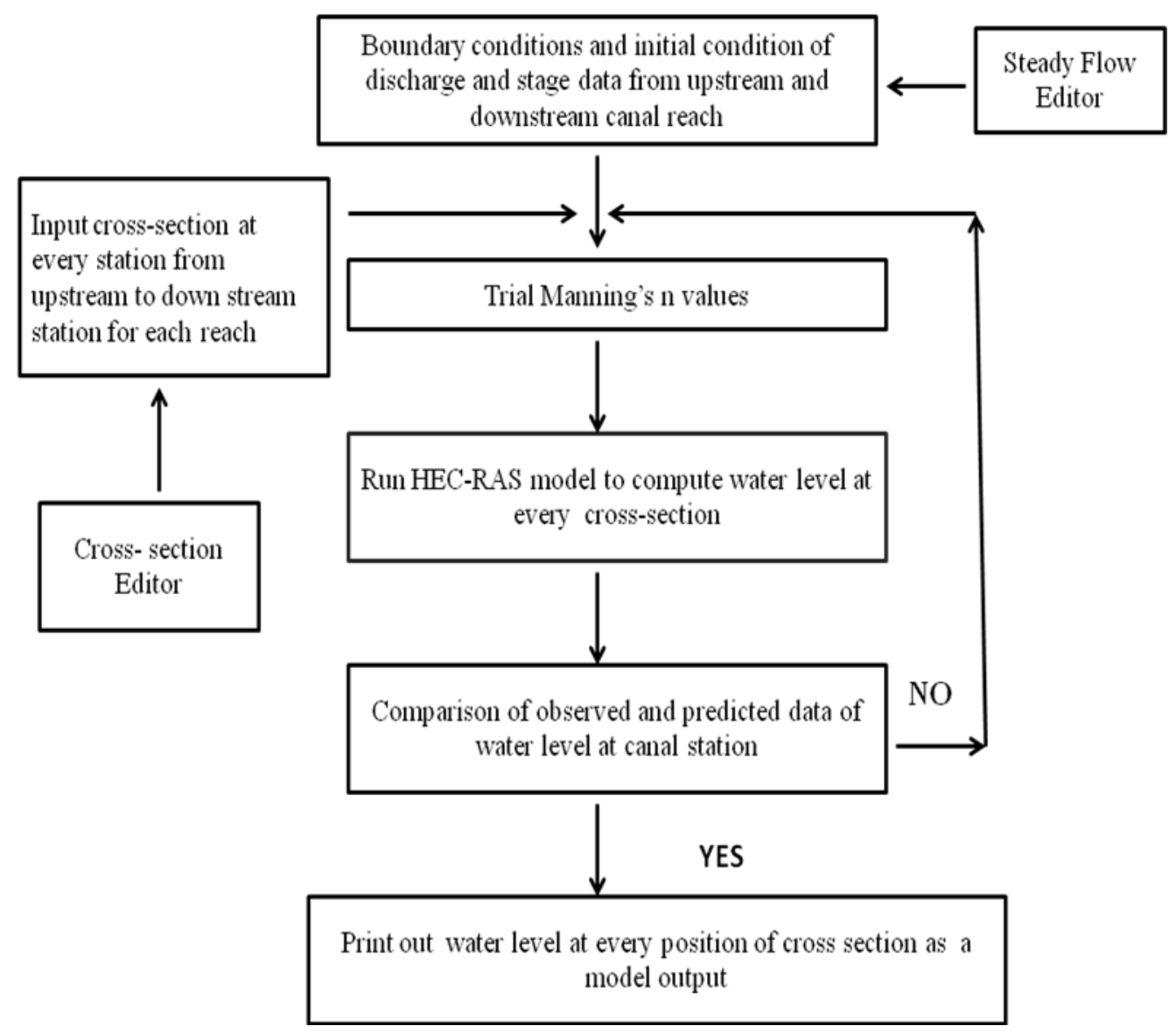

Fig.2 Sample HEC RAS model data input screen

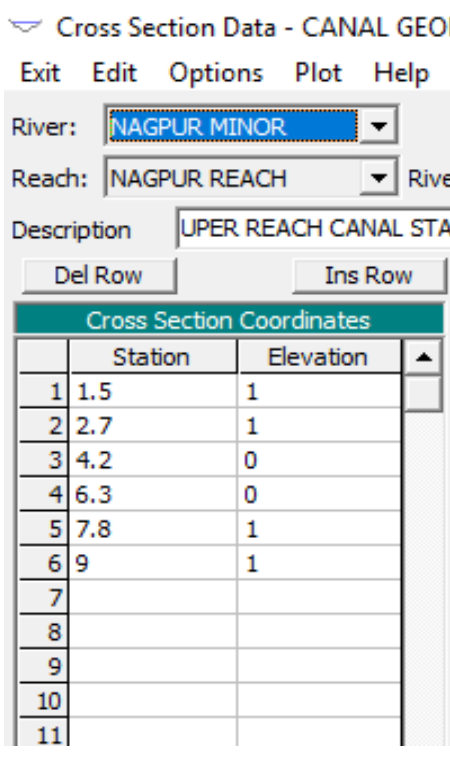

Boundary conditions and initial condition of downstream canal reach

Trial Manning's n values every cross-section
Steady Flow Editor 
Fig.3 Observed water depth verses simulated water depth at canal station 5

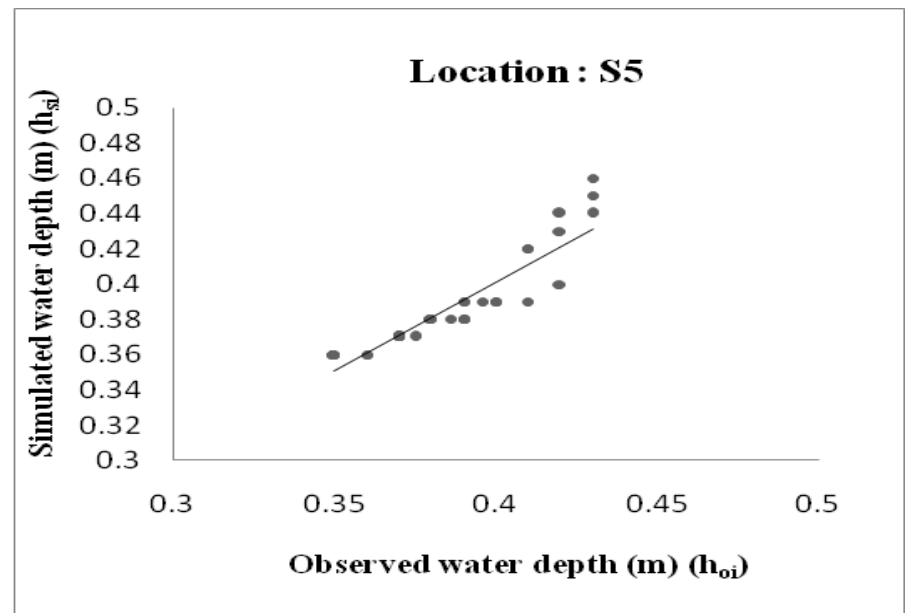

Fig.4 Observed water depth verses simulated water depth at canal station 4

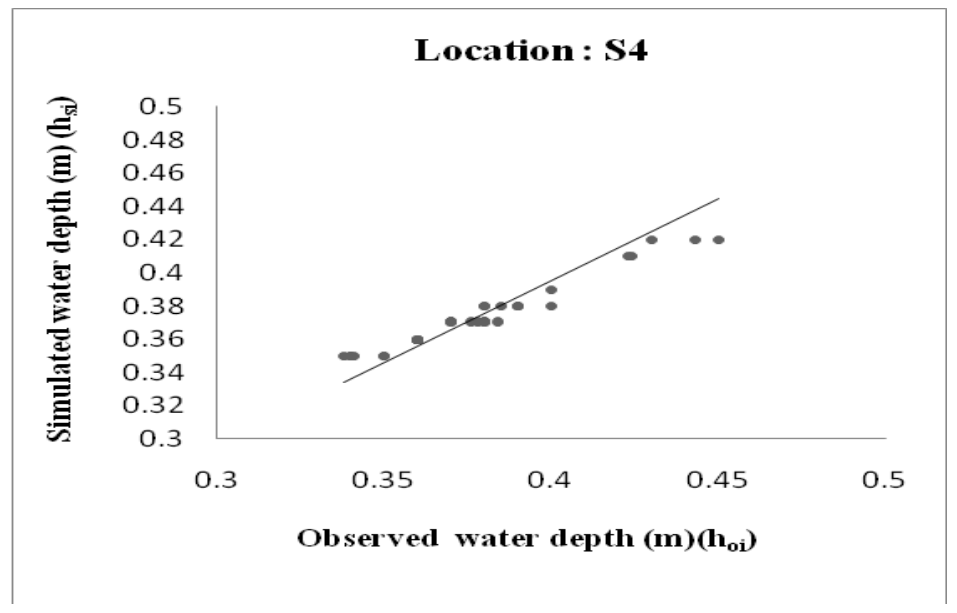

Fig.5 Observed water depth verses simulated water depth at canal station 3

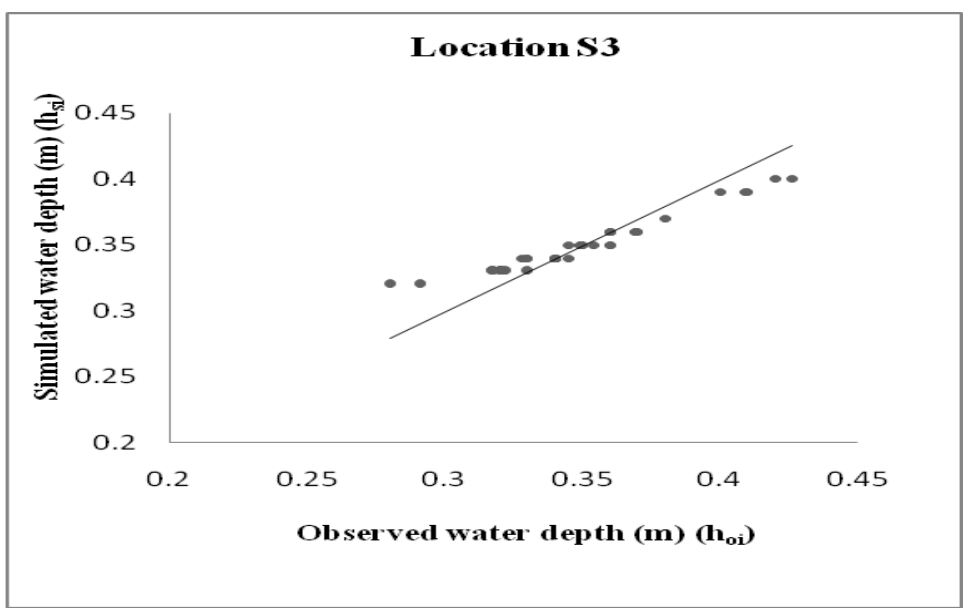


Fig.6 Observed water depth verses simulated water depth at canal station 2

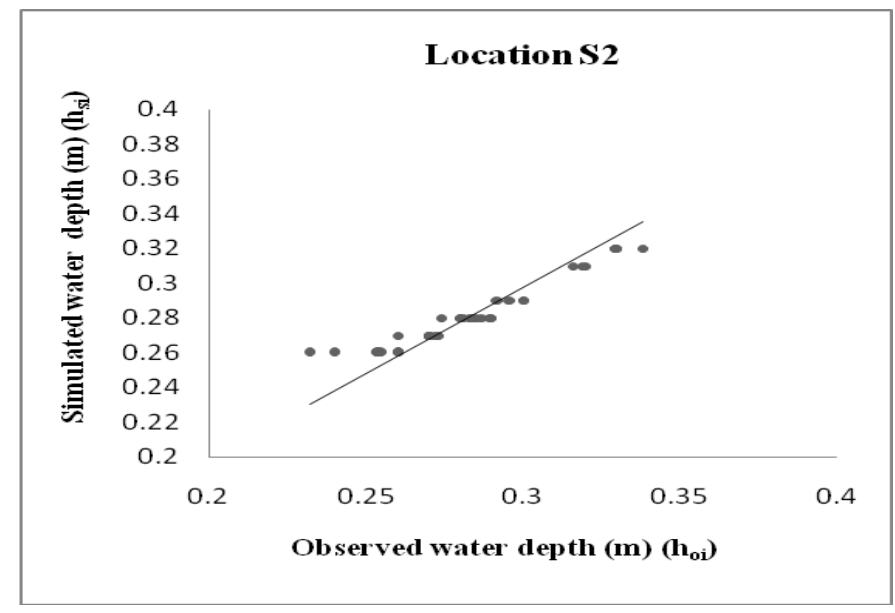

Fig.6 Observed water depth verses simulated water depth at canal station 1

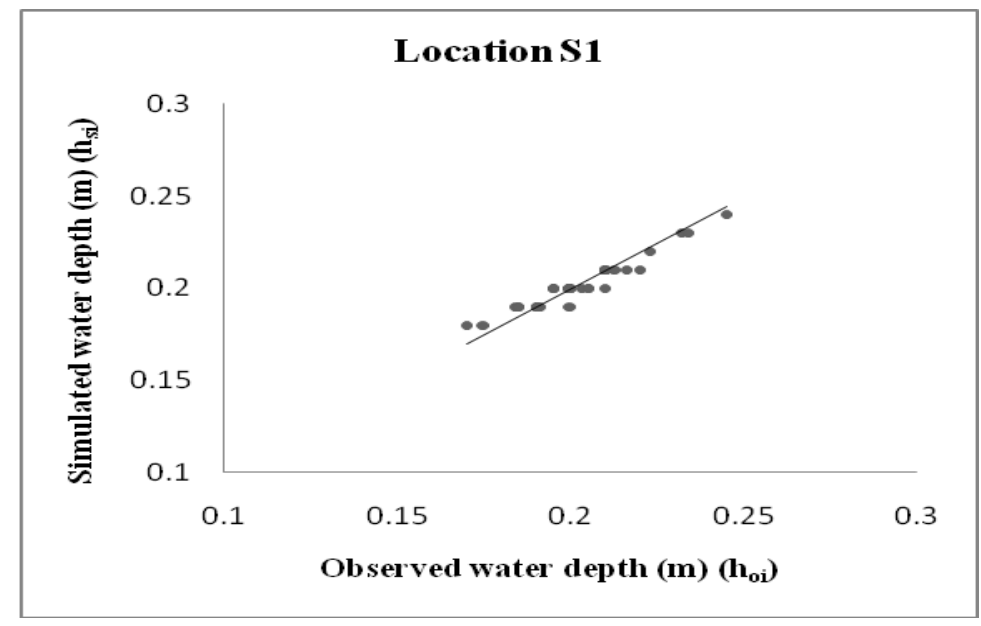

Fig.7 Observed water depth verses simulated water depth at station 5

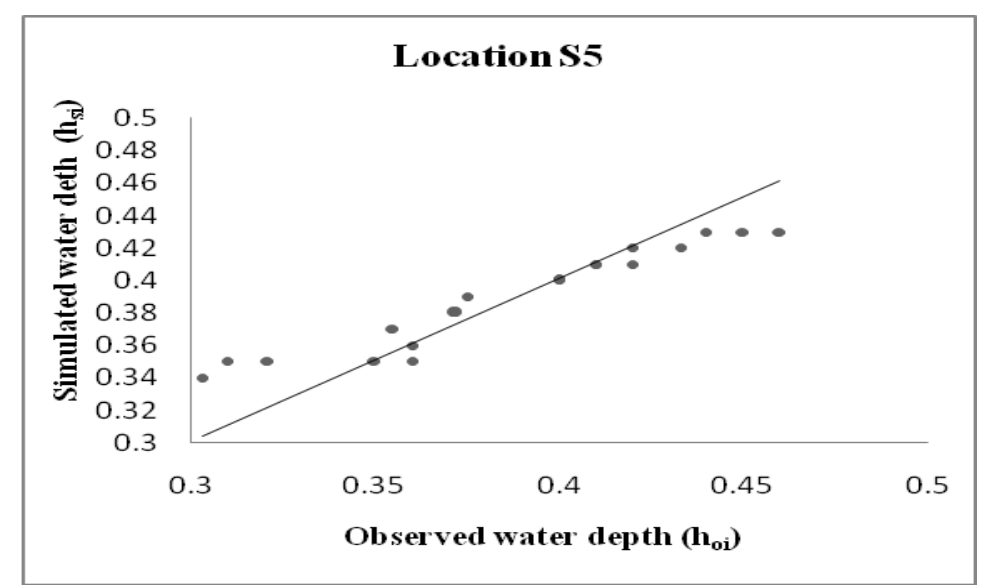


Fig.8 Observed water depth verses simulated water depth at station 4

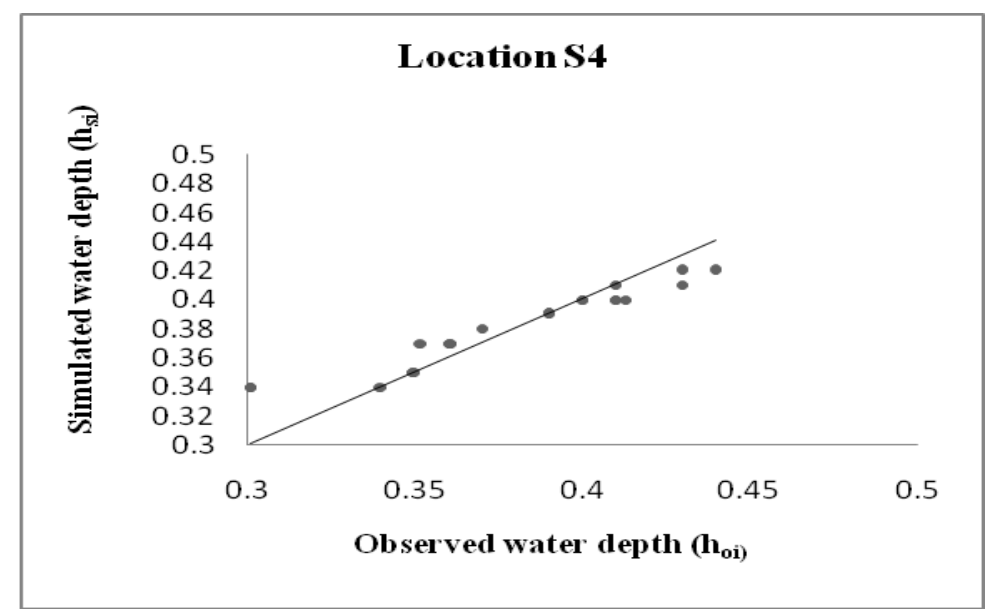

Fig.9 Observed water depth verses simulated water depth at station 3

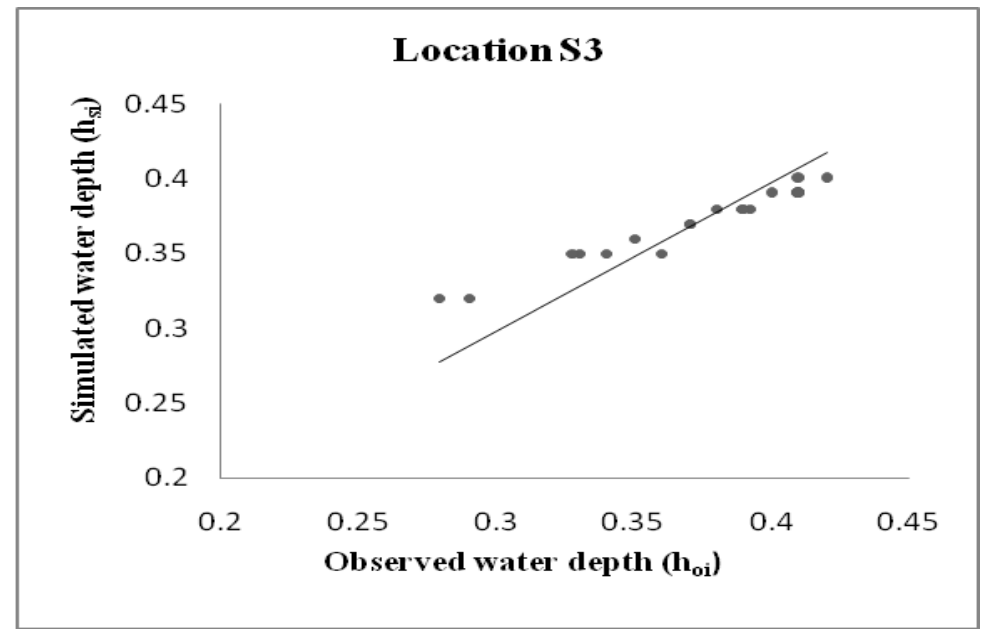

Fig.10 Observed water depth verses simulated water depth at station 2

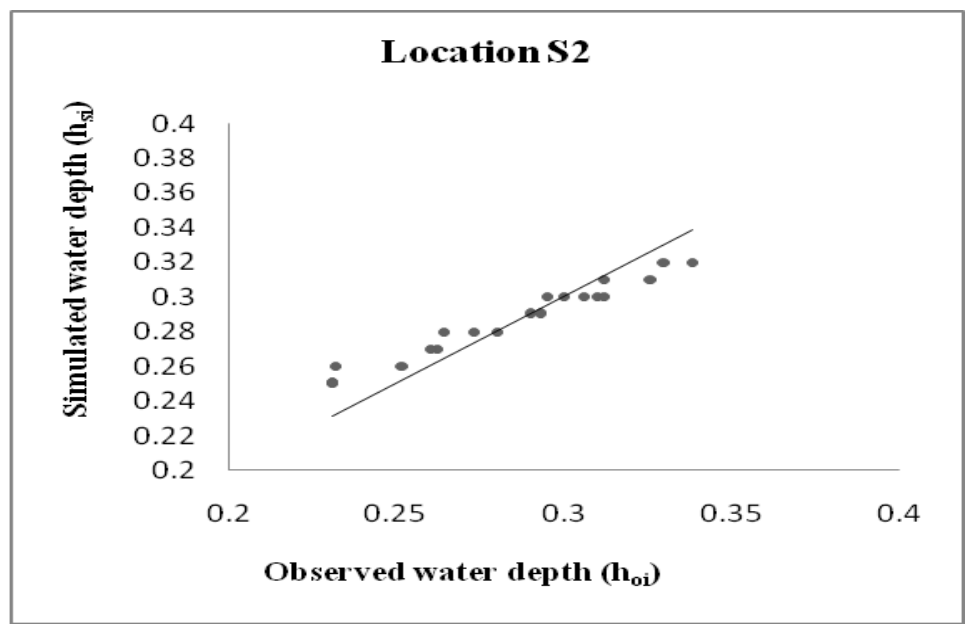


Fig.11 Observed water depth verses simulated water depth at station 1

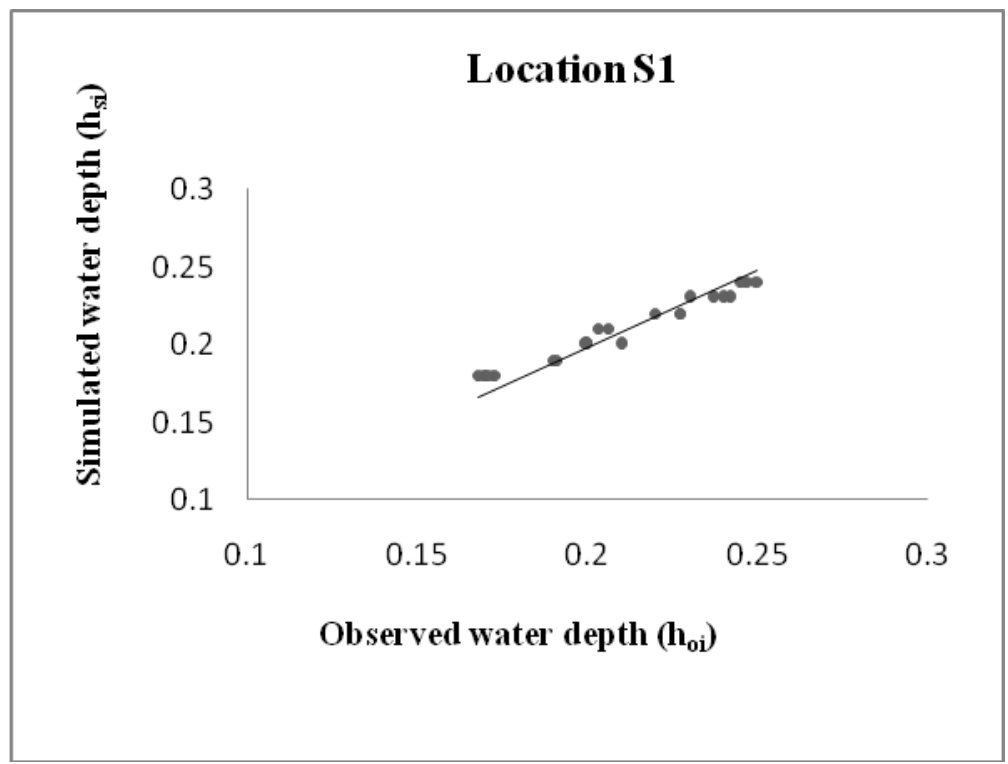

Conclusions of the study are as follows:

The only parameter i.e. Manning's roughness coefficient used for calibration and validation (on daily event based discharge data for the year 2018) in HEC RAS model was obtained as 0.0165 for the Nagpur minor canal.

The performance of the calibrated and validated model has been verified using six statistical indicators (NSE, RMSE, N RMSE, $r$ MAE and SEE). The values of MAE, SEE and RMSE values are on lower side and the values of NSE and $r$ are on a higher side, which indicates the relatively superior simulation of model at all locations, and a close agreement is seen between the observed water depth and simulated water depth.

\section{Acknowledgement}

Authors acknowledge their sincere thanks to the ICAR-Indian Institute of Water Management Bhubaneswar, Odisha for providing the facility for analysis of data and financial assistance for presenting the data for the benefit of user community.

\section{References}

Bandara, K.M.P.S. (2003). Monitoring irrigation performance in Sri Lanka with highfrequency satellite measurements during the dry season. Agricultural water management 58(2):159-170.

Chaw, V. T. (1959). Open channel flow. New York, McGraw Hill Publishers

DeVries, J. J., Tod, I.e., and Jensen M.R. (2004) Study of the Hydraulic Performance of the East Branch, California Aqueduct, J. Amorocho Hydraulics Laboratory, Department of Civil and Environmental Engineering, University of California, Davis.

Droogers, P., Kite, G.W. and Bastiaanssen, W.G.M. (1999). Integrated basin modeling to evaluate water productivity, Proc. 17th Congress ICID, Question 48, R1.01, vol.1A, 11-19 September, Granada, Spain:1-13.

Hameed, Khadim, Luay and Ali Taw Feek, Salah (2013). Estimating of Manning's Roughness Coefficient for Hill River through Calibration Using HEC-RAS model. Jordan Journals of Civil Engineering (JJCV), volume 7, No. 1 2013. 
HEC-RAS, "User Manual" US Army Corps of Engineers, Hydrologic Engineering Center, David Version 5.0, 2016.

Hong Mi-Eun, Choi Youg-Jin and Ho-Won (2016). Assessment of water delivery efficiency in irrigation canals using performance indicators. Irrigation Science DOI 10.1007/s00271-016-0488-6.

Imbenzi J. Serede, Benedict M. Mutua, James M. Raude (2014). A Review for Hydraulic Analysis of Irrigation Canals Using HEC-RAS Model: A Case Study of Mwea Irrigation Scheme, Kenya. Hydrology. Vol. 2, No. 1, 2014, pp. 1-5.

Islam A., Raghuwanshi S.N. and Singh R. (2008). Development and Application of Hydraulic Simulation Model for Irrigation Canal Network. Journals of Irrigation and Drainage Engineering Vol. 134, No. (1): 49-59.

Kumar, Arun, R., and Ambujam, K., N. (2010). Performance assessment of canal irrigation system. ISH Journal's of Hydraulic Engineering, 16(1): 146-155.

Kumar, P., P., Sankhua, R.N. and Roy, G.P. (2012). Calibration of channel roughness for Mahanadi River (India), using HECRAS Model. Journals of water resources and protection, 4: 847-850.

Mehta Darshan, Yadav M.S. Dr., Waikhom Sahita 2013. Geomorphic channel Design and Analysis using HEC-RAS Hydraulic Design Functions. Journals of Global Research Analysis, 3(4): 2277-8160.

M. Shayannejad, K, Askari-Ali Ostad S, Eslamian, VP Singh and NR Dalezios (2018). Analyzing of flow in open channels networks using HEC-RAS. Journal of Ecology \& Natural Research
Vol. 2, Issue 4 , ISSN:2578-4994.

Parhi Kumar Prabeer. (2013). HEC-RAS Model for Manning's Roughness: A Case Study Open Journal of Modern Hydrology. 3, 97-103.

Parhi, P., K., Sankhua, R.N. and Roy, G.P. 2013. HEC-RAS Model for Manning's Roughness: A Case Study. Journal of Water Resource and Protection, 4: 847850.

Patel, Prem, Lal., Timbadiya, P., V. and Porey, R.., D. (2011). Calibration of HEC-RAS model prediction of flood for lower Tapi River, India. Journal of water resources and protection, 3(6): 5-11.

Roude, M., James, Mutua, M., and SeredeJ. (2015). Hydraulic Analysis of Irrigation Canals Using HEC-RAS Model: A Case Study of Mwea Irrigation Scheme, Kenya. International Journals of Engineering Research and Technology (IJERT), 4(9): 985-1005.

Subramanya, K1991. Flow in open channel's Tata McGraw-Hill, New Delhi.

Tebeba, Mamuye and Ayana, Mekonen. (2015). Hydraulic performance evaluation of Hare community managed irrigation scheme, southern, Ethiopia. International research journal of engineering and technology, (2) (08): 901-909.

Timbadiya, P. V., Patel, P. L., and Porey, R.D. (2011). Calibration of HEC-RAS model prediction of flood for lower Tapi River, India. Journal of water resources and protection, 3, (6): 5-11.

U.S. Army Corps of engineers (2016). HECRAS: hydraulic reference manuals.

\section{How to cite this article:}

Vedmani, Rabindra Kumar Panda and Vinay Kumar Pandey. 2020. Calibration and Validation of HEC-RAS Model for Minor Command in Coastal Region. Int.J.Curr.Microbiol.App.Sci. 9(02): 664-678. doi: https://doi.org/10.20546/ijcmas.2020.902.082 